\title{
Education, information, and knowledge
}

\section{Elaine Unterhalter ${ }^{*}$ Nigel Poole ${ }^{\dagger}$ and Niall Winters ${ }^{\ddagger}$}

*University College London Institute of Education, Department of Humanities and Social Sciences, ${ }^{\dagger}$ School of Oriental and African Studies, Centre for Environment, Development and Policy, ${ }^{\ddagger}$ University of Oxford, Department of Education

\section{What is the historical process by which goal setting in this sector has developed?}

Universal primary education (UPE) was formalised in 2002 as the second MDG (Achieve universal primary education). MDG 2 has one target: to ensure that, by 2015, children everywhere, boys and girls alike, will be able to complete a full course of primary schooling. Three indicators are associated with the target: the net enrolment ratio in primary education for girls and for boys; the proportion of pupils starting grade 1 who reach (rather than complete) grade 5; and the literacy rate of 15-24-year-olds. This narrow focus on enrolment, primary school, and literacy for only one age group represented a significant narrowing of the remit of a wider rights-based formulation of global ambitions with regard to education, which had grown for over half a century.

Some of the focus of MDG 2 can be traced back to the Universal Declaration of Human Rights, which enshrined the right of all to education in 1948. This had a scope that was wider than formal schooling, taking in adult literacy, concerns with equality, and a stress on education for peace. In the 1960s, UNESCO sponsored regional conferences to promote the ideas of universal, compulsory, and free education, with a focus on both primary schooling and adult literacy. A number of rights-based international instruments,

\section{How to cite this book chapter:}

Unterhalter, E, Poole, N, and Winters, N. 2015. Education, information, and knowledge. In: Waage, J and Yap, C. (eds.) Thinking Beyond Sectors for Sustainable Development. Pp. 51-61. London: Ubiquity Press. DOI: http://dx. doi.org/10.5334/bao.g 
sponsored by agencies of the United Nations, expanded discussion of the right to education in the 1970s and 1980s. These focussed on aspects of women's rights, the content of education, and social and economic rights. The adoption of the Convention on the Rights of the Child in 1989, which a large number of governments ratified, paved the way for additional policy momentum on the Education for All (EFA) movement.

The World Conference on Education for All, held in Jomtien, Thailand in March 1990, attended by 4 organisations of the United Nations, 155 governments, and $150 \mathrm{NGOs,} \mathrm{was} \mathrm{one} \mathrm{of} \mathrm{the} \mathrm{first} \mathrm{post-Cold} \mathrm{War} \mathrm{convening}$ conferences, and adopted the World Declaration on EFA. The vision was of universalising the right to education, with additional stress on forms of exclusion associated with gender, location, and poverty. The UNICEF World Summit on Children, held in New York in September 1990, placed an emphasis on child health and education, identifying a wider range of issues than just UPE, including early childhood development, vocational training, and preparation for employment, and also stressed the importance of developing strategies for measurement and evaluation.

The follow-up EFA conference in Dakar, Senegal in June 2000 identified the development of Education Management Information Systems (EMIS) as a key means to track policy delivery. The Dakar Framework for Action (2000) identified six goals:

Goal 1: Expanding and improving comprehensive early childhood care and education, especially for the most vulnerable and disadvantaged children.

Goal 2: Ensuring that by 2015 all children, particularly girls, children in difficult circumstances and those belonging to ethnic minorities, have access to and complete free and compulsory primary education of good quality.

Goal 3: Ensuring that the learning needs of all young people and adults are met through equitable access to appropriate learning and life skills programmes.

Goal 4: Achieving a 50 per cent improvement in levels of adult literacy by 2015, especially for women, and equitable access to basic and continuing education for all adults.

Goal 5: Eliminating gender disparities in primary and secondary education by 2005 , and achieving gender equality in education by 2015 , with a focus on ensuring girls' full and equal access to and achievement in basic education of good quality.

Goal 6: Improving every aspects of the quality of education, and ensuring their excellence so that recognised and measurable learning outcomes are achieved by all, especially in literacy, numeracy and essential life skills (EFA, 2000). 
It can be seen that the target identified under MDG 2, with the stress on UPE, was narrower than the six Dakar EFA Goals. Although MDG 2 had an indicator on measuring young adult literacy, it did not articulate the vision of the Dakar Framework with regard to adult literacy, and did not address the question of quality.

MDG 3 (Promote gender equality and empower women) included a target on gender parity in primary, secondary, and tertiary education. This too, was an attenuation of the vision with regard to gender expressed in the Dakar Framework, which itself was a narrowing of a much broader articulation of goals concerned with gender, education, and women's rights set out in the United Nations Fourth World Conference on Women and the Beijing Declaration of 1995.

\section{What progress has been achieved in this sector through the Millennium Development Goals and other processes?}

The formulation of MDG 2 and the six Dakar goals helped mobilise an alliance between international and national policy makers, education activists at a national and international level, and a research community. This grouping is sometimes referred to as the EFA movement (Mundy \& Manion 2015). One strand of the EFA movement was concerned with approaches to monitoring progress on the EFA goals and the MDGs. From 2002, UNESCO published an annual Global Monitoring Report on Education for All (GMR-EFA), which led the way on governments' data collection systems and contributed to debates emerging about what could and should be measured in relation to EFA (Unterhalter 2014a).

The MDGs and EFA goals have been influential in providing a policy and advocacy framework as a means of attracting and channelling development assistance, and in shaping a particular range of desired outcomes. Up to about 2010 they had considerable influence on the modalities of development interventions, although thereafter a number of themes, which were less straightforward to monitor and measure, such as learning outcomes, skills, gender equality, schoolrelated gender-based violence (SRGBV), and higher education, began to attract considerable concern on a national and international level. Early childhood care, which was in the Dakar goals but not the MDGs, was seen as crucial for improving children's readiness for school, enhancing nutrition, and supporting women's education

With respect to EFA's six goals, the following summary can be provided with regard to progress:

EFA Goal 1 Early childhood care and education (ECCE): Globally, considerable progress has been made in achieving ECCE, but progress is uneven. Early childhood health is improving in some countries where measurement has been effected; child mortality and malnutrition rates have declined in many countries in all regions of the world. The 
MDGs target for child mortality, on the other hand, is unlikely to be met. 2012 calculations indicate under five mortality at 48 deaths per 1,000 live births, equivalent to 6.6 million deaths, while in Africa and South Asia 25 per cent of children were short for their age (i.e. suffering from stunting), indicating a lack of essential nutrients in the early years (UNESCO 2014: 45), and causing irreversible damage to development potential among such children. Enrolment in preschool programmes has expanded over the past decade, but there is a wide range of providers, many of them in the private and informal sector, and there is concern at difficulties in delivering care that focuses on early childhood education and not just minimal supervision. Only 68 out of 141 countries with available data will have more than 80 per cent of pre-school-aged children in ECCE programmes in 2015 (UNESCO 2014: 45).

EFA Goal 2 Universal primary education: On current trends, the target for universal primary education will be missed; although the number of out-of-school children of primary school age was reduced from 108 million in 1999 to 57 million in 2011, 54 per cent of whom are girls (UNESCO 2014: 52). Half of the children out of school live in conflictaffected countries. There has been a significant expansion of enrolment in sub-Saharan Africa, but in 201122 per cent of children from this region were out of school, and only 50 per cent completed the full primary cycle. The rate of reduction was rapid between 1999 and 2004, but then started slowing, and progress has stalled since 2008. It is estimated that in 2015, only 68 out of 122 countries will achieve UPE, and in 15 countries less than 80 per cent of children in the age range from primary school will be enrolled (UNESCO 2014: 52).

EFA Goal 3 Youth and adult skills: Participation in lower secondary school increased from 72 per cent to 82 per cent of children in that age range between 1999 and 2011, but in low-income countries only about a third of children complete this level, and for families in the lowest income quintile it is only 14 per cent (UNESCO 2014: 62). Inequalities in completing lower secondary school are associated with income, gender, and location.

EFA Goal 4 Improving adult literacy: The global adult illiteracy rate fell from 24 per cent in 1990 to 16 per cent in 2011 . However in some countries, particularly in Africa and South and West Asia, the combination of limited programmes to address adult illiteracy and rising populations have meant that the numbers of adults who cannot read and write has grown. Women comprise 66 per cent of adult illiterates (UNESCO 2014: 70)

EFA Goal 5 Gender parity and equality in education: Gender parity (the ratio of girls to boys) is a much attenuated measure of gender equality, which entails issues associated with what is learned, how girls and boys are treated, and what happens after school. Some of the discussion about 
goals and targets focused on how better to measure gender equality in education (Unterhalter 2014a). In 2011, only 60 per cent of countries with data had achieved gender parity in primary enrolments. In 2015 it is projected that in 12 countries, there will be only nine girls enrolled in school for every 10 boys. At secondary education level only 38 per cent of countries with available data had achieved gender parity. Poverty, ethnicity, and rurality have considerable bearing on which girls and boys enrol and remain in school (UNESCO 2014: 76).

EFA Goal 6 The quality of education: UNESCO calculations indicated that universal primary completion will not be achieved for the poor in some countries for two generations, while attainment in literacy and numeracy was lowest for the most vulnerable (UNESCO 2014: 95-98). In many areas, the expansion of enrolments was not accompanied by the training of more teachers, and large classes with inadequate facilities were common. There was considerable interest in undertaking citizen-led or other national programmes of learning assessment to hold governments accountable for the quality of education. Analyses of the MDGs show a similar pattern. The MDGs Report of 2014 finds that the enrolment rate for primary-school-aged children rose from 83 per cent to 90 per cent between 2000 and 2012. Most of the gains were achieved by 2007 , after which progress stagnated (United Nations 2014: 5). The numbers who could not read and write were high, at 781 million adults and 126 million youths, 60 per cent of whom are women (United Nations 2014: 16). Gender disparities are more prevalent at higher levels of education, and although many women work, family-friendly policies have not been developed, limiting the ways that home and school might complement each other.

The goals set by the MDGs are now seen by many to have been important but insufficient, in that they aimed for universality of only primary level education (the first five or six years of schooling) and for the achievement of literacy. For young adults, MDG 2 neglects post-primary school access, the quality of learning, adult literacy, and engagements with gender equality in education that go beyond parity. It says nothing about secondary and tertiary level education, although expansion of access and improvement of quality in these sectors are crucial both to generate the teachers to expand the education system and to deliver on all the other MDGs.

In debates about what focus should be given to EFA beyond 2015 and to the place of education in the SDGs, a number of key themes emerged, namely:

Access: Achieving UPE, with renewed emphasis on learning outcomes and teaching about a number of key themes, including global citizenship and sustainability. Access to secondary and post-secondary education became major concerns. 
Equity and equality: This became a major thread in the discussion with concern regarding defining this in terms of features of social exclusion associated with gender, socio-economic status, ethnicity, and location, focusing on strategies for measurement, and posing a range of ethical questions regarding what issues a focus on equalities raised (McCowan \& Unterhalter 2015).

Quality: Extensive discussion took place on how to define education quality (Alexander 2014; Tikly \& Barrett 2013), and what this would mean if quality came to be included in the SDGs and post-2015 EFA. There were differences in view as to whether quality entailed inputs, such as numbers of trained teachers or textbooks, or whether it was associated with outputs, such as numbers of children attaining a particular level of learning. Some stressed that quality was a feature of learning and teaching relationships and processes (Alexander 2014), and others linked it with cultivating particular dispositions associated with social justice (Tikly 2011). Despite these contestations, a number of policy analysts stressed the importance of equipping education systems to deliver education efficiently in order to secure goal attainment (Barber and Mourshed 2007).

\section{Sustainable development goals}

2015 was both the date for the review of the Dakar goals on EFA and achievement of the MDGs. Thus intense debate was generated in the education and international development community on the experience with these frameworks and what should replace them (for examples see Mundy \& Manion 2015; Post2015.org: what comes after the MDGs?; Sayed et al. 2013; Sayed \& Rashid 2014; Unterhalter 2014a; Unterhalter 2014b). After an initial period when it seemed that the SDGs education goal and the post-2015 EFA framework might look very different, there is now considerable alignment. The Muscat Agreement of 2014 (EFA 2014), reached after a series of meetings of member states and interested NGOs convened by UNESCO, sets outs seven targets for EFA under an overarching goal (Ensure equitable and inclusive quality education and lifelong learning for all by 2030). This goal is linked with seven new global education targets:

Target 1: By 2030, at least $\mathrm{x} \%{ }^{5}$ of girls and boys are ready for primary school through participation in quality early childhood care and education, including at least one year of free and compulsory pre-primary education, with particular attention to gender equality and the most marginalised.

\footnotetext{
${ }^{5}$ The targets for the education goal are still under discussion and have not yet been set.
} 
Target 2: By 2030, all girls and boys complete free and compulsory quality basic education of at least 9 years and achieve relevant learning outcomes, with particular attention to gender equality and the most marginalised.

Target 3: By 2030, all youth and at least $\mathrm{x} \%$ of adults reach a proficiency level in literacy and numeracy sufficient to fully participate in society, with particular attention to girls and women and the most marginalised.

Target 4: By 2030, at least $\mathrm{x} \%$ of youth and $\mathrm{y} \%$ of adults have the knowledge and skills for decent work and life through technical and vocational, upper secondary and tertiary education and training, with particular attention to gender equality and the most marginalised.

Target 5: By 2030, all learners acquire knowledge, skills, values and attitudes to establish sustainable and peaceful societies, including through global citizenship education and education for sustainable development.

Target 6: By 2030, all governments ensure that all learners are taught by qualified, professionally-trained, motivated and well-supported teachers.

Target 7: By 2030, all countries allocate at least 4-6\% of their Gross Domestic Product (GDP) or at least $15-20 \%$ of their public expenditure to education, prioritising groups most in need; and strengthen financial cooperation for education, prioritising countries most in need.

It can be seen that these targets correspond to education phases (pre-primary, primary, and basic), but that UPE has now been extended so that the vision is that all children complete nine years of good-quality, basic education. There is now an explicit target with regard to upper secondary and tertiary level education, and vocational education is mentioned. While EFA does not address the content of education, the Muscat Agreement mentions, under Target 5, learning for global citizenship and sustainable development. The Dakar Framework on EFA did not mention teachers, while the Muscat Agreement has an explicit target relating to training teachers. It also requires countries to spend a set proportion of GDP and public expenditure on education, prioritising the marginalised.

The recommendations in the Open Working Group proposal for Sustainable Development Goals (2014) were very similar, although the draft had also included targets around disability and education facilities. In the first four subgoals of the education goal for the SDGs (Goal 4), the main articulation of gender is 'eliminate gender disparities in education', thus focusing on (dis)parity rather than equality. In the other education goals gender is spoken of in terms of access, completion, learning outcomes, literacy, and numeracy. Gender equality is also highlighted as one of the areas of knowledge to be promoted in relation to sustainable development. There is also a concern with genderequitable learning environments. These two threads go beyond the Muscat Agreement, which has dropped the gender goal in the Dakar Framework and is treating gender largely as a matter of counting numbers of girls and boys 
participating at different levels. One of the issues feminist commentators have raised is whether the lack of attention to gender issues in the education goal provides the knowledge and understanding to address gender inequalities and violence, as outlined in the proposed gender goal.

\section{What is the current debate about future goal setting?}

The education goal recommended by the Open Working Group looks very similar to that outlined at Muscat. The goal is to 'Ensure inclusive and equitable quality education and promote lifelong learning opportunities for all'. A broader objective must be to ensure coherence and exploit synergies with other development goals. It is clear that through expanding lifelong learning opportunities for all, education also has the potential to contribute to other SDGs; the SDGs concerned with poverty and economic development are but one example.

Social and economic development in poor regions and countries is closely associated with the concept of 'sustainable livelihoods', which are the capabilities, assets, and activities required for a means of living. The education and development literatures have not been well integrated in this livelihoods context. From an economic perspective, formal education can partly be conceived as a form of capital-building, which can prepare individuals and communities to engage effectively with challenges beyond the classroom. Thus a life-skills approach to formal education is a condition for personal development, responsible citizenship, productive livelihoods, and sustainable economic development (Poole et al. 2013).

An example of this is Mexico, where education has long been considered critical for economic development, and past policies and investment in education have addressed the limited concepts of enrolment and attendance, failing to meet issues of progression, quality, and relevance, even by Latin American standards (Santibañez, Vernez \& Razquin 2005). There are stark regional disparities in terms of education, infrastructure, and poverty, with indigenous groups worse off in terms of illiteracy levels, gender equity, and basic infrastructure.

Mexico's conditional cash transfer programme is part of the social development strategy called Progresa, begun in 1997 and renamed Oportunidades in 2002. Among other things, it offers financial grants for children and young people up to the age of 22 to participate in formal education between the third grade of primary school and the third grade of secondary school. By 2005 the programme covered 24 per cent of the population, including practically all the households living in extreme poverty, most of whom are rural (Levy 2006). Nevertheless, access does not equate to quality: Oportunidades does not address the need for improving the quality of education, student progression, or the educational performance of the system as a whole. Developing and emerging 
economies and regions should prioritise effective and efficient rural education, which incorporates practical and technical skills appropriate to the rural context, and which will prepare young people to participate in the development of rural areas. The demand for viable rural economies will persist, with increasing opportunities for developing dynamic, innovative, and modern businesses within a profitable agricultural base. Educational policies must be tailored with targeted programmes of support, 're-skilling' young people to overcome the barriers to local development and enabling the exploitation of new opportunities (Poole et al. 2013).

New information and communication technologies (ICTs) create new opportunities for learning for disadvantaged peoples that are much more flexible. Consistent with the argument that EFA at primary level is affordable, resources need to be reallocated in order to address local objectives, with specific budgetary attention given to the hard-to-reach, especially in terms of learning technology. New ICT has the potential to formulate a superior pedagogy, allowing interactivity that is now the standard for communication. This needs well-educated teachers, with formal training designed specifically for the particularities of specific systems, like tele-education. There is also an important role for teachers in facilitating learning in addition to direct teaching. In the case of ethnic and linguistic minorities, the cultural and language situation is usually problematic: clear communication between students and teachers is important, requiring language skills for teachers appropriate to the communities among which they work. Decentralisation of education policy can sometimes address some of these issues, leading to new pedagogical models and language skills, improved teacher training, and classroom performance.

In a development context, formal education will interact strongly with issues such food security and health, and rural economic development opportunities pose challenges for standards of formal education. This is particularly the case in Africa where the education components of the SDGs need to facilitate not just formal participation in schooling, but engagement with the process of sustainability in its widest sense. Karembu has written with regard to food production in Africa:

'Agriculturalists agree that the long-term sustainability of existing food production systems will largely depend on appropriate uptake and application of modern science and technologies. Education, empowerment and motivation of young people to take up agricultural activities are a prerequisite for improved and sustainable food production in Africa given their big numbers. However, this is not an overnight endeavour and calls for long-term investment and an overhaul of agricultural education curricula and support systems that enable the youth to apply agricultural innovations in a pleasurable and profitable way. The mass media have an important role in changing this perception. With better opportunities for access to technologies, entrepreneurial skills and social marketing, young people could funnel their youthful idealism, energy and determination into a positive force for change within the agricultural sector. 
This would ultimately result in sustainable production of the food required to support the growing population in Africa' (Karembu 2013: 97).

Similar themes and visions in other SDGs make particular demands of the education goals that still appear too narrowly focussed to provide this range of learning. This need for a broader integration of education and other development goals is explored further in the last chapter of this book.

\section{References}

Alexander, R. (2014 February). Teaching and learning: The quality imperative revisited. Keynote address at Conference of the Norwegian National Commission for UNESCO, Norad, the Norwegian Refugee Council and the University of Oslo, Oslo, Norway. Retrieved from http://www.robinalexander. org.uk/wp-content/uploads/2014/02/Alexander-Oslo-GMR-2014B.pdf

Barber, M. \& Mourshed, M., (2007) How the World's Best Education Systems Come Out on Top, London \& New York: McKinsey. Retrieved from http:// mckinseyonsociety.com/downloads/reports/Education/Worlds_School_ Systems_Final.pdf

Education for All (EFA). (2000) The Dakar Framework for Action - Education for All: Meeting Our Collective Commitments. Paris: UNESCO Retrieved from http://www2.unesco.org/wef/en-conf/dakframeng.shtm

Education for All (EFA). (2014). Muscat Agreement Post 2015 EFA goals and targets. Paris: United Nations Educational, Scientific and Cultural Organization. Retrieved from https://efareport.wordpress.com/2014/06/04/ the-muscat-agreement-new-proposed-post-2015-global-education-goaland-targets-announced-today/

Karembu, M. (2013). Preparing youth for high-tech agriculture. In: R. B. Heap and D. J. Bennett (Eds.), Insights: Africa's future... can biosciences contribute? 91-97. Cambridge: Banson Publishers.

Levy, S. (2006). Progress against poverty: sustaining Mexico's ProgresaOportunidades Program. Washington DC: Brookings Institution Press.

McCowan, T., \& Unterhalter, E. (2015). Education and international development: practice, policy and research. London: Bloomsbury.

Mundy, K., \& Manion, C. (2015). The Education for All initiative: history and prospects post-2015. In: T. McCowan \& E. Unterhalter (Eds.), Education and international development: practice, policy and research 49-68. London: Bloomsbury.

Open Working Group of the General Assembly on Sustainable Development Goals. (2014) Open Working Group proposal for Sustainable Development Goals document A/68/970. New York: United Nations. Retrieved from http://undocs.org/A/68/970 
Poole, N. D., Alvarez, F., Vazquez, R., \& Penagos, N. (2013). Education for All and for what? Life-skills and livelihoods in rural communities. Journal of Agribusiness in Developing and Emerging Economies, 3(1), 64-78.

Post-2015.org: what comes after the MDGs? Retrieved from www http:// post2015.org/

Santibañez, L., Vernez, G., \& Razquin, P. (2005). Education in Mexico: challenges and opportunities. Santa Monica, CA: RAND Corporation.

Sayed, Y., \& Rashid A. (2014). Education quality, and teaching and learning in the post-2015 education agenda. International Journal of Educational Development, 40, 330-338.

Sayed, Y., Sprague, T., UNESCO, UNICEF, Turner, D., Smith, A., Paulson, J., et al (2013). Post-2015 education and development - contestation, contradictions and consensus. Compare forum special issue on post-2015 education and development agenda. Compare, 43(6). DOI: http://dx.doi.org/10.1 080/03057925.2013.850285

Tikly, L. (2011). Towards a framework for researching the quality of education in low-income countries, Comparative Education, 47(1), 1-23.

Tikly, L \& Barrett, A (2013), 'Education quality and social justice in the South: Towards a conceptual framework'. in: L Tikly, A Barrett (eds) Education Quality and Social Justice in the South: Challenges for policy, practice and research. Routledge, 11-24

United Nations. (2014). The Millennium Development Goals Report 2014. New York: United Nations.

United Nations Educational, Scientific and Cultural Organization (UNESCO). (2014). Teaching and learning: achieving quality education for all. Paris: UNESCO.

Unterhalter, E. (2014a). Measuring education for the Millennium Development Goals: reflections on targets, indicators, and a post-2015 framework. Journal of Human Development and Capabilities, 15(1-2), 176-187.

Unterhalter, E. (2014b). Walking backwards to the future: a comparative perspective on education and a post-2015 framework. Compare, 44(6), 852-873 
